\begin{tabular}{|l|l|l||}
\hline \multicolumn{2}{|c|}{ PublisherInfo } \\
\hline \hline PublisherName & $:$ & BioMed Central \\
\hline \hline PublisherLocation & $:$ & London \\
\hline \hline PublisherImprintName & $:$ & BioMed Central \\
\hline \hline
\end{tabular}

\title{
Caught by the secretory-trap
}

\begin{tabular}{|l|l|l||}
\hline \multicolumn{2}{|c|}{ ArticleInfo } \\
\hline \hline ArticleID & $:$ & 4137 \\
\hline \hline ArticleDOI & $:$ & $10.1186 /$ gb-spotlight-20010704-01 \\
\hline \hline ArticleCitationID & $:$ & spotlight-20010704-01 \\
\hline \hline ArticleSequenceNumber & $:$ & 208 \\
\hline \hline ArticleCategory & $:$ & Research news \\
\hline \hline ArticleFirstPage & $:$ & 1 \\
\hline \hline ArticleLastPage & $:$ & 2 \\
\hline \hline & & RegistrationDate : 2001-07-04 \\
ArticleHistory & $:$ & OnlineDate $\quad$ 2001-07-04 \\
\hline \hline ArticleCopyright & $:$ & BioMed Central Ltd2001 \\
\hline \hline ArticleGrants & $:$ & \\
\hline \hline ArticleContext & $:$ & 130592211 \\
\hline \hline
\end{tabular}




\section{Jonathan B Weitzman}

Email: jonathanweitzman@hotmail.com

The gene-trap strategy can exploit insertional mutagenesis to allow phenotypic screening. In the July issue of Nature Genetics, Mitchell et al. demonstrate the power of gene-trap mutagenesis for genomewide analysis of the genes involved in mouse development (Nature Genetics 2001, 298:241-24). Their modified 'secretory-trap' vector selects genes that have secretory signal sequences or transmembrane domains. Screening over 500 insertions in mouse embryonic stem (ES) cells identified 187 individual trapped genes, including 43 novel genes. Mitchell et al. phenotypically analyzed a set of 60 lines. They report high levels (over 90\%) of germ-line transmission, and the generation of null or strong hypomorphic alleles in most cases. The insertions caused recessive phenotypes in $40 \%$ of mutant lines, including embryonic lethality ( 7 lines), neonatal death (8 lines) and severe postnatal phenotypes ( 7 lines). This report demonstrates the powerful application of gene-trap technology to genome analysis and contributes to a broad effort to create a library of insertional mutations.

\section{References}

1. Mouse embryonic stem cells and reporter constructs to detect developmentally regulated genes

2. Nature Genetics, [http://genetics.nature.com]

3. Capturing genes encoding membrane and secreted proteins important for mouse development.

4. University of California Resource of Gene Trap Insertions, [http://www.genetrap.org] 